\title{
'Latestar' Strawberry
}

\author{
G.J. Galletta ${ }^{1}$, J.L. Maas ${ }^{2}$, and J.M. Enns ${ }^{3}$ \\ Fruit Laboratory, Plant Science Institute, Beltsville Agricultural Research \\ Center, Agricultural Research Service, U.S. Department of Agriculture, \\ Beltsville, MD 20705
}

\section{J.C. Scheerens ${ }^{4}$}

Department of Horticulture and Crop Science, The Ohio State University, Ohio Agriculture Research and Development Center, Wooster, OH 44691

\section{R.J. Rouse $\mathbf{s}^{5}$}

Cooperative Extension Service, University of Maryland Eastern Shore, Wye Research and Education Center, Queenstown, MD 21658

\section{R.F. Heflebower, Jr. ${ }^{6}$}

Cooperative Extension Service, University of Maryland, Western Maryland Research and Education Center, Keedysville, MD 21756

\section{Additional index words. Fragaria $\times$ ananassa, Phytophthora fragariae, red stele root rot resistance, fruit breeding}

The 'Latestar' Junebearing strawberry (Fragaria $\times$ ananassa Duch.) was introduced for propagation to American nurseries in Apr. 1995 by the U.S. Dept. of Agriculture. 'Latestar' was selected for its high plant vigor and runnering and high yields of attractive and large fruit with firm flesh and tough skin; glossy red skin; light-red flesh; pleasant and mild, slightly acidic, fresh flavor; and resistance to the red stele root rot disease (incited by Phytophthora fragariae Hickman). Plants of 'Latestar' are resistant to most of the common leaf diseases and fruit rots encountered in the Mid-Atlantic area, but susceptible to the leaf blight disease [incited by Phomopsis obscurans (Ellis \& Everh.) Sutton]. 'Latestar' produces well on either light or heavy soils, in matted-row or in raised-bed culture, planted in spring or summer, and usually flowers and ripens its fruit slightly later than do 'Allstar', 'Lateglow', or 'Jewel'.

'Latestar' is expected to be best adapted to the Mid-Atlantic and adjacent regions and is suggested for trial there as an attractive, large,

\footnotetext{
Received for publication 22 Mar. 1996. Accepted for publication 22 July 1996 . We are indebted to A. Funk, Millersville, Pa.; E.J Hanson, Michigan State Univ., East Lansing; M.L. Kaps and M.B. Odneal, Southern Missouri Fruit Experiment Station, Mountain Grove; J.J. Luby and D. Wildung, Univ. of Minnesota, St. Paul and Grand Rapids; and T. Nourse, South Deerfield, Mass., for evaluating the suitability of 'Latestar' for their areas. The cost of publishing this paper was defrayed in part by the payment of page charges. Under postal regulations, this paper therefore must be hereby marked advertisement solely to indicate this fact.

${ }^{1}$ Research Geneticist.

${ }^{2}$ Research Plant Pathologist.

${ }^{3}$ Horticulturist.

${ }^{4}$ Associate Professor, Horticulture.

${ }^{5}$ Regional Specialist, Fruits and Vegetables.

${ }^{6}$ Regional Specialist, Fruits.
}

and productive late-season shipping and local market cultivar with multiple fungus disease resistance.

'Latestar' was named for its parents, 'Lateglow' and 'Allstar'.

\section{Origin and testing history}

'Latestar', tested as MDUS 5084, was a seedling from the 1978 cross of 'Lateglow' $x$ 'Allstar', made at Beltsville, Md., by G.J.G. Seedlings from this cross were screened for resistance to a five-race composite of the red stele root rot inciting fungus in a greenhouse test at Beltsville during Winter 1978-79. Resistant seedlings were transplanted in Spring 1979 to a field at the Univ. of Maryland experimental farm at the Wye Research and Education Center, Queenstown, on Maryland's Eastern Shore. 'Latestar' was selected in 1980 by G.J.G. Plants of the selection were retested for resistance to five races of $P$. fragariae.

'Latestar' was evaluated at Beltsville during the period 1981-95, and was sent for testing to cooperating scientists in Maryland, Michigan, Minnesota, Missouri, New Jersey, and Ohio, and cooperating growers in Massachusetts and Pennsylvania. 'Latestar' plants were increased by micropropagation from virus-negative mother stocks and were released to nursery operators in 1995 and to the public in 1996.

Production test methods. 'Latestar' was established in Beltsville with several standard cultivars (Galletta, 1989) in either 3- or 1.5-mlong plots, $0.3 \mathrm{~m}$ between plants, and $1 \mathrm{~m}$ between plots on a sandy soil in a matted-row system in 1987-93. Overhead irrigation for frost protection and drip-tubing supplemental irrigation were provided. Cultivars and selections were compared for plant-making ability, leaf disease reactions, plant vigor, flowering time, total and marketable yields, primary and mean fruit mass, and ripening season. Fruit of each cultivar were evaluated for appearance, symmetry, skin and flesh firmness, external and internal color, and flavor, from which an overall fruit quality index was computed for each genotype. Laboratory tests were conducted on fruit of several cultivars, including 'Latestar', to determine total soluble solids (TSS), soluble sugar, titratable acids (TA), organic acids, and ascorbic acid concentrations (Wang et al., 1996).

'Latestar' and several standard cultivars were established in 6.5 -m-long matted-row plots replicated four times on a Matapeake silt loam soil in 1993 at the Univ. of Maryland Wye Research and Education Center. Beds were $0.6 \mathrm{~m}$ wide and spaced $1.3 \mathrm{~m}$ apart. A duplicate planting of cultivars also was established at the Univ. of Maryland Western Maryland Research and Education Center in Keedysville, Md., in a heavy, Hagerstown silt loam soil. Entire plots were harvested in 1994 and center 3.5-m-long portions of plots were harvested in 1995. Mean fruit mass was estimated by averaging the masses of four replicate samples of 25 fruit at the midharvest time for each cultivar.

In Wooster, Ohio, 'Latestar' and standard cultivars (Luby, 1989) were established in 2$\mathrm{m}$-long plots in a matted-row system on a Wooster silt loam soil in 1990. Beds were 0.6 $\mathrm{m}$ wide and spaced $1 \mathrm{~m}$ apart and plants spaced $0.6 \mathrm{~m}$ apart in beds. Fruit samples were obtained at full ripeness in 1991 and 1992 and objectively evaluated for quality characteristics. Fruit from the second harvest of each cultivar were combined over replications; representative samples of seven fruit each were obtained and fruit were evaluated individually for TSS by refractometry of hand-expressed juice; skin and flesh firmness (in 1992) by the method of Ourecky and Bourne (1968) using an Instron 1101 firmness tester (Instron Corp., Canton, Mass.) equipped with a $0.95-\mathrm{cm}$ star punch (Dunkley Co., Kalamazoo, Mich.); cortex firmness (in 1991) by Instron analysis using a $3.2-\mathrm{mm}$ cylindrical probe passed through the cortical tissue of a $1-\mathrm{cm}$-thick axial fruit slice; and external (skin) color at three sites and internal (flesh) color at two sites per fruit using equipment (CR-100 chromameter; Minolta Corp. Meter Div., Ramsey, N.J.) and techniques similar to those described by Sacks and Shaw (1993). Raw color data (L*, $\left.\mathrm{a}^{*}, \mathrm{~b}^{*}\right)$ were transformed according to Setser (1984) to values of $\mathrm{L}$, hue angle (arctan $\mathrm{b} / \mathrm{a})$, and saturation index $\left(\mathrm{a}^{2}+\mathrm{b}^{2}\right)^{1 / 2}$. In addition, $\approx 200 \mathrm{~g}$ of fruit of each cultivar was frozen for TA analysis. At a later date, these samples were thawed and then pureed; duplicate 10-g subsamples were extracted with $90 \mathrm{~mL}$ of neutralized $\mathrm{H}_{2} \mathrm{O}$. The extracts were filtered through a qualitative grade filter paper, then 25-mL aliquots of filtrate were titrated against $0.1 \mathrm{~N} \mathrm{NaOH}$ to an endpoint of $\mathrm{pH}$ 8.1. Indices of earliness and concentration of fruit maturation also were made for each cultivar using methods adapted (Brenneman and Scheerens, 1994) from Khanizadeh and Fanous (1992).

In Aug. 1994, 'Latestar' was established in double rows on nonfumigated raised beds mulched with black plastic in Beltsville. Plants were spaced $0.3 \mathrm{~m}$ apart and $0.3 \mathrm{~m}$ between 
rows in each bed. Trickle tubing was placed in the center of each raised bed beneath the mulch for supplemental irrigation and fertigation. Raised-bed plots consisted of six plants as double rows of three plants each.

All plantings were established in a randomized complete-block design with four replications for each entry. Due to the varying number of cultivars, harvests, and sites represented, a separate analysis of variance was performed for each set of plant-season-location data. All means comparisons were made by Duncan's multiple range test at $P \leq 0.05$.

'Latestar' also was evaluated in a semicommercial, nonreplicated trial in Millersville, Pa., on a very fertile loam soil in 1992-94 to obtain performance and fruit quality estimates under grower conditions.

Fruit production. In Beltsville, total yields of 'Latestar' in 1988, 1990, and 1994 equalled or were higher than those of 'Kent', 'Allstar', 'Honeoye', 'Lateglow', and 'Lester', but were less than those of 'Glooscap' in 1988 and 'Chambly' in 1994 (Table 1). In 1991, the yield of 'Latestar' was less than those of 'Kent' and 'Lateglow'. In Queenstown, 'Latestar' yields were as high or higher than those of 'Delmarvel', 'Glooscap', and 'Lateglow', but less than those of 'Allstar' and 'Cavendish' in 1994. However, in 1995, 'Latestar' yields were similar to those of the other cultivars. In Keedysville, 'Latestar' yields were as high or higher than those of 'Delmarvel' and 'Lateglow', but less than those for 'Allstar', 'Cavendish', and 'Delmarvel' in 1994 (Table 2). In Wooster, the 2-year average of total yields of 'Latestar' equalled those of 'Allstar', 'Earliglow', and 'Lateglow' (Table 3). In Mountain Grove, in a 3-year study, total yields of 'Latestar' in $1987\left(1.42 \mathrm{~kg} \cdot \mathrm{m}^{-1}\right.$ of row $)$ equalled those of 'Allstar', 'Arking', 'Canoga', 'Guardian', 'Jewel', and 'Lester', and the percentages of marketable fruit of 'Latestar' (60\%) equalled those of 'Allstar', 'Jewel', and 'Lester', but were lower than those of 'Arking', 'Canoga', and 'Guardian' (Kaps et al., 1990). In the second and third years of the trial, total yields of 'Latestar' $\left(3.76 \mathrm{~kg} \cdot \mathrm{m}^{-1}\right.$ in 1988 and $2.17 \mathrm{~kg} \cdot \mathrm{m}^{-1}$ in 1989) were higher than those of the other cultivars, except those of 'Allstar' in 1988 and 1989. 'Latestar' total yields on raised beds in Beltsville in 1995 were as high or higher than those of the other cultivars (Table 4).

The percentages of marketable fruit of 'Latestar' in Beltsville in 1988, 1990, 1991, and 1994 generally equalled or were higher than those of the other cultivars, with the exception of 'Lateglow' in 1988 (Table 1). In Wooster, the 2-year average percentages of marketable fruit for 'Latestar' equalled those of 'Allstar' and 'Lateglow', but were less than that of 'Earliglow' (Table 3). In Mountain Grove, the percentages of marketable fruit of 'Latestar' in 1987 (60\%) equalled those of 'Allstar', 'Jewel', and 'Lester', and in 1988 $(88 \%)$ and $1989(73 \%)$ were similar to or higher than those of 'Guardian', 'Arking', 'Allstar', 'Jewel', 'Lester', and 'Canoga' (Kaps et al., 1990). 'Latestar' percent marketable yield on raised beds in Beltsville in 1995 was

Table 1. Fruit production of 'Latestar' and several standard strawberry cultivars grown in matted-row beds in Beltsville, Md., in 1988, 1990, 1991, and 1994.

\begin{tabular}{|c|c|c|c|c|c|}
\hline \multirow[b]{3}{*}{ Cultivar } & \multicolumn{2}{|c|}{ Yield } & \multirow{2}{*}{\multicolumn{2}{|c|}{$\begin{array}{c}\text { Fruit mass }{ }^{y} \\
(\mathrm{~g})\end{array}$}} & \multirow{3}{*}{$\begin{array}{c}\text { Proportion } \\
\text { through fourth } \\
\text { harvest }(\%)\end{array}$} \\
\hline & \multirow{2}{*}{$\begin{array}{l}\text { Total } \\
\left(\mathrm{t} \cdot \mathrm{ha}^{-1}\right)\end{array}$} & \multirow{2}{*}{$\begin{array}{c}\text { Marketable }^{\mathrm{z}} \\
(\%) \\
\end{array}$} & & & \\
\hline & & & Primary & Season & \\
\hline \multicolumn{6}{|c|}{1988} \\
\hline Allstar & $34.3 \mathrm{ab}^{\mathrm{x}}$ & $86 a b$ & 25.2 & $15.1 \mathrm{a}$ & $32 \mathrm{~b}$ \\
\hline Glooscap & $41.4 \mathrm{a}$ & $71 \mathrm{c}$ & 22.1 & $11.5 \mathrm{~b}$ & $27 \mathrm{~b}$ \\
\hline Honeoye & $29.6 \mathrm{c}$ & $78 \mathrm{~b}$ & 24.4 & $13.3 \mathrm{ab}$ & $55 \mathrm{a}$ \\
\hline Kent & $37.6 \mathrm{ab}$ & $77 \mathrm{~b}$ & 25.9 & $13.0 \mathrm{ab}$ & $21 \mathrm{~b}$ \\
\hline Lateglow & $22.0 \mathrm{~d}$ & $87 \mathrm{a}$ & 23.3 & $12.3 \mathrm{~b}$ & $31 \mathrm{~b}$ \\
\hline Latestar & $32.7 \mathrm{~b}$ & $80 \mathrm{~b}$ & $23.0^{\mathrm{Ns}}$ & $12.0 \mathrm{~b}$ & $9 \mathrm{c}$ \\
\hline \multicolumn{6}{|c|}{1990} \\
\hline Allstar & $19.4 \mathrm{~b}$ & $84 \mathrm{a}$ & $23.5 \mathrm{ab}$ & $13.3 \mathrm{ab}$ & $32 \mathrm{~b}$ \\
\hline Glooscap & $27.6 \mathrm{a}$ & $74 \mathrm{~b}$ & $17.6 \mathrm{c}$ & $9.7 \mathrm{~b}$ & $45 \mathrm{a}$ \\
\hline Jewel & $20.4 \mathrm{~b}$ & $81 \mathrm{a}$ & $21.3 \mathrm{c}$ & $15.2 \mathrm{a}$ & $10 \mathrm{c}$ \\
\hline Lateglow & $17.7 \mathrm{~b}$ & $88 \mathrm{a}$ & $20.8 \mathrm{~b}$ & $10.7 \mathrm{ab}$ & $21 \mathrm{bc}$ \\
\hline Latestar & $26.8 \mathrm{a}$ & $81 \mathrm{a}$ & $27.1 \mathrm{a}$ & $13.3 \mathrm{ab}$ & $13 \mathrm{c}$ \\
\hline \multicolumn{6}{|c|}{1991} \\
\hline Allstar & $20.6 \mathrm{ab}$ & 80 & 21.1 & $12.7 \mathrm{a}$ & $8 \mathrm{~b}$ \\
\hline Kent & $21.3 \mathrm{a}$ & 77 & 21.2 & $11.8 \mathrm{ab}$ & $22 \mathrm{ab}$ \\
\hline Lateglow & $22.5 \mathrm{a}$ & 83 & 20.4 & $10.2 \mathrm{a}-\mathrm{c}$ & $31 \mathrm{a}$ \\
\hline Latestar & $12.9 \mathrm{~b}$ & $73^{\mathrm{Ns}}$ & $15.3^{\mathrm{Ns}}$ & $8.4 \mathrm{c}$ & $0 \mathrm{c}$ \\
\hline \multicolumn{6}{|c|}{1994} \\
\hline Allstar & $14.2 \mathrm{~b}$ & $89 a$ & $20.5 \mathrm{ab}$ & 12.2 & $41 \mathrm{bc}$ \\
\hline Chambly & $22.5 \mathrm{a}$ & $73 \mathrm{c}$ & $16.4 \mathrm{ab}$ & 9.9 & $55 \mathrm{ab}$ \\
\hline Jewel & $17.1 \mathrm{ab}$ & $80 \mathrm{bc}$ & $19.4 \mathrm{ab}$ & 11.6 & $29 \mathrm{~cd}$ \\
\hline Lester & $14.2 \mathrm{~b}$ & $84 \mathrm{ab}$ & $21.4 \mathrm{a}$ & 10.9 & $59 \mathrm{a}$ \\
\hline Latestar & $12.0 \mathrm{~b}$ & $82 a b$ & $15.6 \mathrm{~b}$ & $10.5^{\mathrm{Ns}}$ & $18 \mathrm{~d}$ \\
\hline
\end{tabular}

${ }^{2}$ Percent of total yield less culls due to small size, misshapen fruit, disease, etc.

${ }^{y}$ Mean individual primary and season fruit mass were estimated from four replicate samples of 25 fruit during early harvests (primary fruit) and for all harvests (season) of each cultivar.

${ }^{x}$ Means separation in colums within years by Duncan's multiple range test at $P \leq 0.05$. Ns indicates no significant differences among cultivars.

Table 2. Yield and mean individual fruit mass of 'Latestar' and several other strawberry cultivars grown in matted-row beds in Queenstown and Keedysville, Md., locations in 1994 and 1995.

\begin{tabular}{|c|c|c|c|c|}
\hline \multirow[b]{2}{*}{ Cultivar } & \multicolumn{2}{|c|}{$\begin{array}{c}\text { Total yield } \\
\left(\mathrm{t} \cdot \mathrm{ha}^{-1}\right)\end{array}$} & \multicolumn{2}{|c|}{$\begin{array}{l}\text { Mean individual fruit } \\
\text { mass at midharvest }(\mathrm{g})\end{array}$} \\
\hline & Queenstown $^{z}$ & Keedysvilley $^{y}$ & Queenstown & Keedysville \\
\hline \multicolumn{5}{|c|}{1994} \\
\hline Allstar & $21.7 \mathrm{a}^{\mathrm{x}}$ & $15.1 \mathrm{a}$ & $15.1 \mathrm{bc}$ & $12.1 \mathrm{~b}$ \\
\hline Cavendish & $23.3 \mathrm{a}$ & $15.0 \mathrm{a}$ & $17.3 \mathrm{a}$ & $14.0 \mathrm{a}$ \\
\hline Delmarvel & $12.9 \mathrm{c}$ & $10.6 \mathrm{~b}$ & $16.4 \mathrm{ab}$ & $10.3 \mathrm{c}$ \\
\hline Glooscap & $15.7 \mathrm{bc}$ & $14.8 \mathrm{a}$ & $13.8 \mathrm{c}$ & $10.6 \mathrm{c}$ \\
\hline Lateglow & $8.0 \mathrm{~d}$ & $10.6 \mathrm{c}$ & $13.5 \mathrm{c}$ & $9.2 \mathrm{c}$ \\
\hline Latestar & $14.2 \mathrm{~b}$ & $11.7 \mathrm{~b}$ & $15.7 \mathrm{ab}$ & $10.4 \mathrm{c}$ \\
\hline \multicolumn{5}{|c|}{1995} \\
\hline Allstar & $24.2 \mathrm{ab}$ & ----w & $18.2 \mathrm{~b}$ & --- \\
\hline Cavendish & $28.1 \mathrm{ab}$ & --- & $19.6 \mathrm{a}$ & --- \\
\hline Delmarvel & $20.0 \mathrm{~b}$ & --- & $15.5 \mathrm{c}$ & --- \\
\hline Glooscap & $29.5 \mathrm{a}$ & --- & $12.7 \mathrm{e}$ & --- \\
\hline Lateglow & $22.1 \mathrm{ab}$ & --- & $12.6 \mathrm{e}$ & --- \\
\hline Latestar & $23.2 \mathrm{ab}$ & --- & $14.0 \mathrm{~d}$ & --- \\
\hline
\end{tabular}

${ }^{2}$ University of Maryland, Wye Research and Education Center, Queenstown.

${ }^{y}$ University of Maryland, Western Maryland Research and Education Center, Keedysville.

${ }^{x}$ Means separation in colums within years by Duncan's multiple range test at $P \leq 0.05$.

"Data not taken.

as high or higher than those of the other cultivars (Table 4).

In a 1992-94 semi-commercial, nonreplicated trial conducted at Millersville, 'Latestar' produced $17.9 \mathrm{t}^{\circ} \mathrm{ha}^{-1}$ in 1993 , compared to 14.7 t.ha ${ }^{-1}$ for 'Cavendish' and $14.4 \mathrm{t}^{\circ} \mathrm{ha}^{-1}$ for 'Raritan'. In the second harvest year (1994), 'Latestar' produced only $6.7 \mathrm{t} \cdot \mathrm{ha}^{-1}$, compared to 14.3 thha ${ }^{-1}$ for 'Cavendish' and $8.5 \mathrm{t}^{\mathrm{h}} \mathrm{h}^{-1}$ for 'Raritan'. 'Latestar' fruit averaged nearly 49 fruit/L, slightly less than for 'Cavendish' and 'Raritan' in the second season. The appearance of 'Latestar' fruit was rated similar to that of 'Cavendish' and 'Lateglow' fruit and the flavor and firmness of 'Latestar' fruit was similar to those of 'Cavendish' fruit. The calyx (cap) of 'Latestar' fruit was rated better in appearance (freedom from disease and desiccation) than for 'Earliglow' fruit (data not shown).

The mean primary fruit mass of 'Latestar' in Beltsville equalled or was higher than that of 'Glooscap', 'Kent', 'Allstar', 'Honeoye', 'Lateglow, or 'Jewel' in 1988, 1990, 1991, and 1994, but was less than that of 'Lester' in 1994 (Table 1). Average mass of 'Latestar' 
Table 3. Two-year means of total and percent marketable yields, mean individual fruit mass and plant stand ratings of 'Latestar' and several standard strawberry cultivars grown in matted-row beds in Wooster, Ohio, in 1991 and 1992.

\begin{tabular}{|c|c|c|c|c|}
\hline \multirow[b]{2}{*}{ Cultivar } & \multicolumn{2}{|c|}{ Yield } & \multirow{2}{*}{$\begin{array}{l}\text { Individual } \\
\text { fruit mass } \\
\text { (g) }\end{array}$} & \multirow[b]{2}{*}{$\begin{array}{c}\text { Stand } \\
\text { (rating) }^{\mathrm{x}}\end{array}$} \\
\hline & $\begin{array}{c}\text { Total } \\
\left(\mathrm{t} \cdot \mathrm{ha}^{-1}\right)\end{array}$ & $\begin{array}{c}\text { Marketable } \\
(\%)\end{array}$ & & \\
\hline Allstar & $22.7^{w}$ & $74 \mathrm{~b}$ & $14.3 \mathrm{a}$ & 9 \\
\hline Earliglow & 17.0 & $82 \mathrm{a}$ & $9.1 \mathrm{c}$ & 8 \\
\hline Lateglow & 18.7 & $75 \mathrm{~b}$ & $13.2 \mathrm{ab}$ & 8 \\
\hline Latestar & $18.0^{\mathrm{NS}}$ & $72 \mathrm{~b}$ & $12.0 \mathrm{~b}$ & 7 \\
\hline
\end{tabular}

${ }^{2}$ Total yield less culls due to misshapen fruits, disease, insect damage, etc.

${ }^{\mathrm{y}}$ Individual fruit mass mean estimated from five replications of 25 fruit taken at the second harvest of each cultivar.

${ }^{x}$ Plant stand ratings on a subjective scale from 1 (not established) to 10 (fully established in a matted-row bed.

"Means separation in columns by Duncan's multiple range test at $P \leq 0.05$. Ns indicates no significant differences.

Table 4. Yield and mean individual fruit mass of 'Latestar' and several other strawberry cultivars summerplanted and grown on raised beds with black plastic mulch and trickle irrigation in Beltsville, Maryland, in 1995 .

\begin{tabular}{|c|c|c|c|c|c|}
\hline \multirow[b]{3}{*}{ Cultivar } & \multicolumn{2}{|c|}{ Yield } & \multirow{2}{*}{\multicolumn{2}{|c|}{$\begin{array}{c}\text { Fruit mass } \\
(\mathrm{g})\end{array}$}} & \multirow{3}{*}{$\begin{array}{c}\text { Proportion } \\
\text { through third } \\
\text { harvest }(\%)\end{array}$} \\
\hline & \multirow{2}{*}{$\begin{array}{c}\text { Total } \\
\left(\mathrm{t} \cdot \mathrm{ha}^{-1}\right)\end{array}$} & \multirow{2}{*}{$\begin{array}{c}\text { Marketable } \\
(\%)\end{array}$} & & & \\
\hline & & & Primary & Season & \\
\hline Allstar & $12.6 \mathrm{a}-\mathrm{c}^{\mathrm{x}}$ & $76 \mathrm{a}$ & $17.5 \mathrm{bc}$ & $11.2 \mathrm{a}$ & $57 \mathrm{ab}$ \\
\hline Guardian & $13.2 \mathrm{ab}$ & $69 \mathrm{ab}$ & $13.4 \mathrm{c}$ & $9.3 \mathrm{ab}$ & $51 \mathrm{~b}$ \\
\hline Jewel & $8.5 \mathrm{c}$ & $65 \mathrm{~b}$ & $23.1 \mathrm{a}$ & $11.4 \mathrm{a}$ & $58 \mathrm{ab}$ \\
\hline Lateglow & $11.4 \mathrm{bc}$ & $68 \mathrm{ab}$ & $14.9 \mathrm{bc}$ & $9.6 \mathrm{ab}$ & $27 \mathrm{c}$ \\
\hline Latestar & $16.4 \mathrm{a}$ & $72 \mathrm{ab}$ & $19.3 \mathrm{ab}$ & $10.9 \mathrm{ab}$ & $23 \mathrm{c}$ \\
\hline Lester & $12.1 \mathrm{a}-\mathrm{c}$ & $77 \mathrm{a}$ & $15.0 \mathrm{bc}$ & $9.1 \mathrm{~b}$ & $65 \mathrm{a}$ \\
\hline
\end{tabular}

${ }^{2}$ Total yield less culls due to small size, misshapen fruit, disease, etc.

${ }^{\mathrm{y}}$ Mean individual primary and season fruit mass were estimated from four replicate samples of 10 fruit during early harvest (primary fruit) and for all harvests (season) of each cultivar.

${ }^{x}$ Means separation within columns by Duncan's multiple range test at $P \leq 0.05$.

fruit in Beltsville in each year equalled those of the standard cultivars, except in 1988 and 1991 when average 'Allstar' fruit mass was higher and in 1991 when 'Kent' average fruit mass was higher. 'Latestar' midseason individual fruit mass was similar to or higher than that of the other cultivars in Queenstown in 1994, and, although 'Latestar' fruit mass was higher than those of 'Glooscap' and 'Lateglow' in 1995, it was less than those of 'Allstar', 'Cavendish', or 'Delmarvel' (Table 2). 'Latestar' midseason individual fruit mass was as high as that of 'Glooscap', 'Delmarvel', or 'Lateglow' in Keedysville in 1994, but less than that of 'Allstar' and 'Cavendish' (Table 2). In Wooster, the 2-year average of mean fruit mass of 'Latestar' equalled or was higher than that of 'Earliglow' or 'Lateglow', but less than that of 'Allstar' (Table 3). In Mountain Grove, the 3-year means of 'Latestar' fruit averaged 8.8 g over the years 1987,1988 , and 1989, slightly less than the means for 'Canoga' (10.8 g), 'Arking' (10.2 g), 'Allstar' (10.0 g), and 'Jewel' (9.0 g) (Kaps, et al., 1990). On raised beds in Beltsville in 1995, 'Latestar' large and mean fruit mass were similar to or higher than those of the other cultivars (Table 4).

'Latestar' did not perform well in southeastern Michigan in a 1991 trial (E. Hanson, personal communication). Plant vigor of 'Latestar' plants (53\% plant stand in the second harvest year) was less than that of 'Lateglow' (90\%) and 'Allstar' (97\%), and contributed to the low yields of 'Latestar' in 1991 and 1992. Although the total yield of 'Latestar' fruit was similar to that of 'Lateglow' in 1991, it was less than that of 'Lateglow' in 1992 (data not shown).

In 1991, 'Latestar' rated highly promising in first year fruiting beds in Grand Rapids, Minn. 'Latestar' yield was similar to that of its 'Allstar' parent, but not quite as high as that of its 'Lateglow' parent or that of 'Jewel'. Individual 'Latestar' fruit mass was as high as any of the cultivars except slightly lower than that of 'Jewel' (data not shown). In South Deerfield, Mass., 'Latestar' had a very high yield of good quality fruit (data not shown).

Fruit characteristics. 'Latestar' fruit characteristics scored uniformly high and similar to or better than standard cultivars in Beltsville in 1988 (Table 5). 'Latestar' fruit scored an average of 7.0 to 7.5 ( $9=$ best $)$ for appearance, symmetry, flesh firmness, skin toughness, external and internal color, and flavor and the fruit quality index (mean of seven quality scores $\times 10$ ) equalled that of 'Allstar' fruit in 1988 and 1994. In Wooster, measurements of cortical firmness (1991) or flesh firmness (cortex + pith, 1992) characterized 'Latestar' fruit as firmer than 'Lateglow' or 'Earliglow' fruit, and with cortical firmness similar to that of 'Allstar' in 1991, but with less flesh firmness than 'Allstar' fruit in 1992 (Table 6). The skin toughness of 'Latestar' fruit was surpassed only by that of 'Allstar'.

In Wooster, tristimulus reflectometry of 'Latestar' fruit skin and flesh characterized the new cultivar as bearing fruit with moderately deep red external pigmentation and with highly colored interiors (Table 7). Based on values for lightness (L), redness (hue angle), and saturation index (pigment intensity), the skin color of 'Latestar' was, perhaps, most similar to that of 'Earliglow' in both test years. Conversely, 'Latestar' fruit skin color was consistently darker and redder than that exhibited by 'Allstar'. Tristimulus ratings for internal fruit color were not as consistent or as definitive as those obtained for external color. However in both years, $L$ and hue angle values indicated 'Latestar' flesh to be darker and more deeply red than that of 'Allstar' fruit, and as, or nearly as highly colored as those of 'Lateglow' or 'Earliglow' fruit. The saturation index for 'Latestar' fruit in 1991 was less than that for the other cultivars, however, in 1992, the differences were not significant.

Fruit TSS and TA of cultivars also varied with year of harvest (1991 and 1992) in Wooster (Table 6), reflecting environmental differences between years during the period of fruit ripening. Temperatures were unusually high during the 1991 fruiting season, which accelerated and compressed ripening patterns of all cultivars in the study (Table 8). Because 'Latestar' usually ripens late within the Junebearer season, its fruit may have matured earlier and more rapidly than normal and with depressed TSS and TA concentrations in 1991. However, despite environmental differences in 1991 and 1992, comparative values for the TSS : TA ratio remained relatively constant among cultivars and suggested that 'Latestar' most closely resembled 'Lateglow' for sugar/acid balance (Table 6).

In Beltsville, the TSS of 'Latestar' fruit $(8.1 \%)$ was less than that of 'Earliglow' and higher than for 'Allstar' and 'Lateglow' fruit (Wang et al., 1996). The TA and citric acid concentration in 'Latestar' fruit was comparable to those of 'Earliglow' fruit, higher than those of 'Allstar' fruit, and less than those of 'Lateglow' fruit.

The total sugar concentration in 'Latestar' fruit $(5.4 \%)$ was higher that of 'Allstar' fruit, similar to that of 'Lateglow' fruit, and less than that of 'Earliglow' fruit (Wang et al., 1996). The glucose : fructose ratio of fruit of each cultivar was quite different. The glucose : fructose ratio of 'Latestar' fruit (1.4) was higher than that of 'Lateglow' (1.1), 'Allstar' (0.6), and 'Earliglow' (0.5) fruit and the total sugar : TA ratio of 'Latestar' (10.2) was less than that of 'Allstar' (11.3), similar to that of 'Earliglow' (10.3), and higher than that of 'Lateglow' (7.2).

Time offlowering and fruit ripening. Plants of 'Latestar' flowered with or slightly after those of 'Lateglow' in Beltsville in 1988 (Table 9). 'Latestar' flowered later than 'Allstar' in 1988 and 1994.

'Latestar' fruit ripen late in the Junebearer season. In Beltsville, 'Latestar' generally ripened later than or with 'Lateglow' and later than the midseason standards planted in matted-row (Table 1) or raised beds (Table 4). Earliness of fruit ripening indices calculated for cultivars grown in Wooster in 1991 and 1992 indicated that 'Latestar' fruit ripened with fruit of 'Allstar' and 'Lateglow' and later than 'Earliglow' in both years (Table 8). Although cultivar $\times$ year interactions were found for ripening of 'Earliglow' and 'Lateglow' 
Table 5. Field rating scores for fruit characters of 'Latestar' strawberry and several standard cultivars grown in matted-row beds in Beltsville, Md., in 1988 and indicies of fruit quality ratings in 1988, 1990, 1991, and 1994

\begin{tabular}{|c|c|c|c|c|c|c|c|c|c|c|c|}
\hline \multirow[b]{3}{*}{ Cultivar } & \multicolumn{7}{|c|}{ Ratings } & & & & \\
\hline & \multirow[b]{2}{*}{ Appearance } & \multirow[b]{2}{*}{ Symmetry } & \multirow{2}{*}{$\begin{array}{c}\text { Flesh } \\
\text { firmness }\end{array}$} & \multirow{2}{*}{$\begin{array}{c}\text { Skin } \\
\text { toughness }\end{array}$} & \multicolumn{2}{|c|}{ Color } & \multirow[b]{2}{*}{ Flavor } & \multicolumn{4}{|c|}{ Fruit quality index ${ }^{z}$} \\
\hline & & & & & External & Internal & & 1988 & 1990 & 1991 & 1994 \\
\hline Allstar & $7-8^{y}$ & 7 & $8-9$ & 8 & $7-8$ & $6-7$ & 7 & 75 & 74 & 75 & 71 \\
\hline Glooscap & $7-8$ & $7-8$ & $7-8$ & $6-8$ & $7-8$ & $7-8$ & 7 & 74 & 70 & $--^{x}$ & --- \\
\hline Honeoye & $6-7$ & $6-7$ & $6-7$ & 6 & $5-7$ & 7 & 7 & 65 & 69 & --- & --- \\
\hline Kent & 7 & $5-8$ & $7-8$ & $6-7$ & $7-8$ & $6-7$ & $6-7$ & 69 & --- & --- & --- \\
\hline Lateglow & 8 & $7-8$ & $7-8$ & 7 & 7 & 7 & 8 & 74 & 76 & 77 & --- \\
\hline Latestar & $7-8$ & $6-8$ & $8-9$ & $7-8$ & $7-8$ & $6-8$ & $7-8$ & 74 & 75 & 74 & 73 \\
\hline Lester & $7-8$ & $7-8$ & $7-8$ & $7-8$ & $7-8$ & $6-7$ & 7 & 73 & 76 & --- & 78 \\
\hline
\end{tabular}

${ }^{\mathrm{z}}$ Averages of the seven listed characters in the first part of the table multiplied by 10 to give whole numbers (90 is a perfect score).

${ }^{y}$ Ratings on a 1 to 9 scale, with 9 being the best quality, and 6 acceptable.

${ }^{x}$ Cultivar not included in this trial.

Table 6. Fruit total soluble solids concentration (TSS), titratable acidity (TA), TSS : TA, and firmness of 'Latestar' strawberry and several standard cultivars grown in matted-row beds in Wooster, Ohio, in 1991 and 1992.

\begin{tabular}{|c|c|c|c|c|c|c|c|c|c|}
\hline \multirow[b]{3}{*}{ Cultivar } & \multirow{2}{*}{\multicolumn{2}{|c|}{ TSS $(\%)$}} & \multirow{2}{*}{\multicolumn{2}{|c|}{ TA $(\%)$}} & \multirow{2}{*}{\multicolumn{2}{|c|}{ TSS : TA }} & \multicolumn{3}{|c|}{ Firmness (N) } \\
\hline & & & & & & & \multirow{2}{*}{$\begin{array}{r}\text { Cortex } \\
1991^{z} \\
\end{array}$} & \multirow{2}{*}{$\begin{array}{l}\text { Flesh } \\
1992^{y}\end{array}$} & \multirow{2}{*}{$\begin{array}{r}\text { Skin } \\
1992^{y}\end{array}$} \\
\hline & 1991 & 1992 & 1991 & 1992 & 1991 & 1992 & & & \\
\hline Allstar & $6.2 \mathrm{a}^{\mathrm{x}}$ & $6.0 \mathrm{~b}$ & $0.61 \mathrm{a}$ & $0.51 \mathrm{c}$ & 10.2 & 11.7 & $0.72 \mathrm{a}$ & $9.07 \mathrm{a}$ & $4.10 \mathrm{a}$ \\
\hline Earliglow & $6.4 \mathrm{a}$ & $7.7 \mathrm{a}$ & $0.58 \mathrm{ab}$ & $0.67 \mathrm{~b}$ & 11.0 & 11.5 & $0.35 \mathrm{~b}$ & $2.71 \mathrm{~d}$ & $2.64 \mathrm{~b}$ \\
\hline Lateglow & $6.1 \mathrm{a}$ & $8.1 \mathrm{a}$ & $0.67 \mathrm{a}$ & $0.88 \mathrm{a}$ & 9.1 & 9.2 & $0.45 \mathrm{~b}$ & $4.27 \mathrm{c}$ & $2.57 \mathrm{~b}$ \\
\hline Latestar & $4.6 \mathrm{~b}$ & $5.4 \mathrm{~b}$ & $0.51 \mathrm{~b}$ & $0.67 \mathrm{~b}$ & 9.0 & 9.0 & $0.58 \mathrm{a}$ & $5.89 \mathrm{~b}$ & $2.75 \mathrm{~b}$ \\
\hline
\end{tabular}

${ }^{2}$ Determined in 1991 by Instron analysis using a 3.2-mm cylindrical probe passed at $50 \mathrm{~mm} \cdot \mathrm{min}^{-1}$ through the cortical tissue of a 1-cm-thick fruit slice from each of seven representative fruits of each cultivar.

${ }^{y}$ Determined in 1992 by Instron analysis using a $0.95-\mathrm{mm}$ diameter star punch passed at $50 \mathrm{~mm} \cdot \mathrm{min}^{-1}$ equatorially through the skin, cortex, and pith tissues of each of seven representative intact fruits of each cultivar.

${ }^{x}$ Means separation in columns within and between years by Duncan's multiple range test at $P \leq 0.05$.

Table 7. Fruit skin and flesh color of 'Latestar' strawberry and several standard cultivars grown in mattedrow beds in Wooster, Ohio, in 1991 and 1992.

\begin{tabular}{|c|c|c|c|c|c|c|}
\hline \multirow[b]{3}{*}{ Cultivar } & \multicolumn{6}{|c|}{ Color criterion } \\
\hline & \multicolumn{2}{|c|}{$\mathrm{L}^{\mathrm{z}}$} & \multicolumn{2}{|c|}{$\begin{array}{c}\text { Hue } \\
\text { angle }^{\mathrm{y}}\end{array}$} & \multicolumn{2}{|c|}{$\begin{array}{c}\text { Saturation } \\
\text { index }^{\mathrm{x}}\end{array}$} \\
\hline & 1991 & 1992 & 1991 & 1992 & 1991 & 1992 \\
\hline \multicolumn{7}{|c|}{ Skin } \\
\hline Allstar & $35.8 \mathrm{a}^{\mathrm{w}}$ & $37.5 \mathrm{a}$ & $35.7 \mathrm{a}$ & $33.3 \mathrm{a}$ & $24.4 \mathrm{a}$ & $28.7 \mathrm{a}$ \\
\hline Earliglow & $29.4 \mathrm{~b}$ & $31.4 \mathrm{c}$ & $32.5 \mathrm{~b}$ & $30.8 \mathrm{~b}$ & $17.2 \mathrm{c}$ & $21.3 \mathrm{c}$ \\
\hline Lateglow & $30.7 \mathrm{~b}$ & $35.1 \mathrm{~b}$ & $32.4 \mathrm{~b}$ & $31.9 \mathrm{ab}$ & $21.7 \mathrm{~b}$ & $26.7 \mathrm{ab}$ \\
\hline Latestar & $31.4 \mathrm{~b}$ & $32.8 \mathrm{c}$ & $32.5 \mathrm{~b}$ & $30.4 \mathrm{~b}$ & $22.4 \mathrm{~b}$ & $25.5 \mathrm{~b}$ \\
\hline \multicolumn{7}{|c|}{ Flesh } \\
\hline Allstar & $51.5 \mathrm{a}$ & $47.7 \mathrm{a}$ & $48.1 \mathrm{a}$ & $43.6 \mathrm{a}$ & $29.3 \mathrm{a}$ & 27.9 \\
\hline Earliglow & $45.7 \mathrm{~b}$ & $47.8 \mathrm{a}$ & $38.8 \mathrm{c}$ & $43.0 \mathrm{a}$ & $33.2 \mathrm{a}$ & 25.9 \\
\hline Lateglow & $45.8 \mathrm{~b}$ & $46.8 \mathrm{a}$ & $41.8 \mathrm{bc}$ & $42.4 \mathrm{ab}$ & $31.4 \mathrm{a}$ & 28.5 \\
\hline Latestar & $44.4 \mathrm{~b}$ & $43.6 \mathrm{~b}$ & $43.8 \mathrm{~b}$ & $39.4 \mathrm{~b}$ & $24.8 \mathrm{~b}$ & $27.8^{\mathrm{Ns}}$ \\
\hline
\end{tabular}

${ }^{2} \mathrm{~L}$ (raw data transformed according to Setser, 1984) $=$ lightness to darkness; $100=$ pure white, $0=$ pure black. ${ }^{\mathrm{y}}$ Hue angle $(\arctan \mathrm{b} / \mathrm{a})$ in degrees, (raw data transformed according to Setser, 1984); 90 = pure yellow, 0 $=$ pure red.

${ }^{x}$ Saturation index $\left(a^{2}+b^{2}\right)^{1 / 2}$ (raw data transformed according to Setser, 1984); higher values indicate higher pigment intensity.

"Means separation in columns within year by Duncan's multiple range test at $P \leq 0.05$. Ns indicates no significant differences among cultivars.

fruit, no similar interaction was observed for 'Latestar' or 'Allstar' fruit ripening. Due to yearly climatic variation, concentration of fruit ripening indices differed among years. However, within years, patterns of concentration in fruit ripening were similar among cultivars (Table 8).

Plant and growth characteristics. Plants of 'Latestar' are vigorous and usually runner well to fill matted-row beds. In Beltsville in 1988, beds of 'Latestar' plants were slightly less full than beds of 'Allstar' and 'Earliglow' plants in Fall 1987, as full in Fall 1993, were rated as high as those of all cultivars in Spring 1988 and 1994 (Table 9). 'Latestar' plant vigor was rated as high as the other cultivars in fall and spring seasons of 1987-88 and 199394. 'Latestar' beds in their first production year (Fall, 1994) in Queenstown were rated $4.5(0=$ no plants, $5=$ ideal bed establishment, and $10=$ too many plants), compared to beds of 'Jewel' (2.0) and 'Mohawk' (9.0) (detailed data not shown). In Keedysville, 'Latestar' beds in their first production year (Fall, 1994) rated 6.2, compared to those of 'Jewel' (3.7) and 'Mohawk' (7.5) (detailed data not shown). In Wooster, beds of 'Latestar' plants were rated thinner than those of 'Allstar' and slightly thinner than beds of 'Earliglow' and 'Lateglow' plants (Table 3). In Mountain Grove, plant stand of 'Latestar' (as percent row-fill) for the planting year (1986) was rated equal to that for the late-midseason standards 'Allstar', 'Arking', 'Canoga', 'Guardian', 'Jewel', and 'Lester' (Kaps et al., 1990).

\section{Disease resistance}

In Beltsville, 'Latestar' plants were tolerant of most late-season leaf diseases, but susceptible to leaf blight (caused by Phomopsis obscurans). Other leaf diseases generally encountered in Beltsville are leaf scorch [caused by Diplocarpon earliana (Ellis \& Everh.) F.A. Wolf] and powdery mildew [Sphaerotheca macularis (Wallr. ex Fr.) Jacz. f.sp. fragariae . 'Latestar' plants were scored similar to or more resistant than 'Allstar', 'Lester', 'Honeoye', 'Lateglow', and 'Earliglow' plants to leaf diseases in Fall 1987 and 1993 and in Spring 1988 and 1994. 'Latestar' plants were scored similar to 'Allstar', 'Honeoye', and 'Lateglow' plants for incidence of leaf diseases in Summer 1988 (Table 9). In a 3-year study in Mountain Grove, plants of 'Latestar' generally were scored less susceptible to leaf spot [incited by Mycosphaerella fragariae (Tul.) Lindau] than either 'Honeoye' (in 1987) or 'Kent' (in 1987 and 1988). The incidence of leaf scorch on leaves of 'Latestar' was less than for 'Jewel' in 1987 and 'Canoga' and 'Guardian' in 1989. Plants of 'Latestar' were rated less susceptible to leaf blight than those of 'Jewel' or 'Lester' in 1987 and 1989 and of 'Canoga' in 1988 and 1989. Kaps et al. (1990) found great variations in leaf disease incidence and severity and cultivar susceptibility during their 3-year study.

'Latestar' plants initially were screened for resistance to the red stele root rot disease as a seedling to a mixture of Phytophthora fragariae races A-1, A-2, A-3, A-4, and A-6 in a greenhouse bench test (Scott et al., 1975). 'Latestar' plants were retested as an advanced selection to confirm its resistance to the red stele disease. On a scale of 1 (dead plant) to 9 (apparently healthy plant), 'Latestar', in a 1989 test, rated about 8.0, indicating that it is resistant to at least these five races of $P$. fragariae (Table 9). In a 1993 test, 'Latestar' plants rated 8.7 for resistance to the five-race mixture (Galletta et al., 1994). 'Latestar' plants were determined in other inoculation tests to also be resistant to race A-7 (Maas and Galletta, unpublished data), a race of California origin and now 
Table 8 . Indices of earliness and concentration cultivar $\times$ year interaction means for fruit production of 'Latestar' and several standard strawberry cultivars grown in matted-row beds in Wooster, Ohio, in 1991 and 1992.

\begin{tabular}{lcccr}
\hline \hline & \multicolumn{2}{c}{ Index of earliness $^{\mathrm{z}}$} & \multicolumn{2}{c}{ Index of concn $^{\mathrm{y}}$} \\
\cline { 2 - 3 } \cline { 5 - 5 } Cultivar & 1991 & 1992 & 1991 & 1992 \\
\hline Allstar & $1.52 \mathrm{~b}^{\mathrm{x}}$ & $1.81 \mathrm{~b}$ & 5.63 & 3.37 \\
Earliglow & $3.22 \mathrm{a}$ & $5.84 \mathrm{a}$ & 5.74 & 3.76 \\
Lateglow & $1.50 \mathrm{~b}$ & $1.25 \mathrm{c}$ & 5.31 & 3.57 \\
Latestar & $1.33 \mathrm{~b}$ & $1.45 \mathrm{bc}$ & $6.13^{\mathrm{Ns}}$ & $3.52^{\mathrm{Ns}}$
\end{tabular}

${ }^{\mathrm{z}}$ Index of earliness adapted (Brenneman and Scheerens, 1994) from Khanizadeh and Fanous, 1992; larger values indicate earlier ripening of fruit compared.

'Index of concentration adapted (Brenneman and Scheerens, 1994) from Khanizadeh and Fanous, 1992; larger values indicate a more concentrated ripening season.

${ }^{x}$ Means separation in columns within and between year by Duncan's multiple range test at $P \leq 0.05$. NS indicates no significant differences among cultivars.

found in Maine (Maas et al., 1988) and Nova Scotia (Nickerson and Murray, 1993).

\section{Technical description}

Plants are medium in crown size and density. Leaf petioles are semierect to procumbent, medium thick, have medium to dense pubescence and sharply pointed stipules. The trifoliolate leaves are a light to medium yellow-green adaxially and light green abaxially, with veins prominent. Leaflet shape is broadly elliptic with oblique bases. Leaflet margins have many serrations that vary in height and width, but that have sharply acuminate tips.

Fruit are large, varying in shape from broadshouldered and blunt-tipped wedge (for primary and secondary fruit) to short conic (for tertiary and later fruit). In hot seasons, some primary fruit may fasciate. Fruit skin color is a bright glossy scarlet that matures to a dark red in very ripe fruit. Achenes are yellow and recessed. Flesh is a uniform medium red. Fruit flesh and skin are firm, the latter also resistant to abrasion. The cap (ripened floral calyx) is clasping and composed of two whorls whose pointed lanceolate and broad member sepals alternate. The fresh fruit is sub-acidic and mildly aromatic in flavor at full maturity, and juicy in texture.

\section{Plant availability}

Interested parties should contact Gene Galletta, USDA/ARS, Fruit Laboratory, 10300 Baltimore Blvd., Beltsville, MD 20705, for a list of nursery sources for 'Latestar' plants.

\section{Literature Cited}

Brenneman, G.L. and J.C. Scheerens. 1994. Performance of new or uncommon strawberry cultivars grown under Ohio cultural conditions. The
Ohio State Univ., OARDC-Wooster, Circ. 298:99-108.

Galletta, G.J. 1989. Northeastern United States strawberry cultivars. Fruit Var. J. 43(1):31-33.

Galletta, G.J., J.L. Maas, and J.M. Enns. 1994. Strawberry cultivar and selection red stele screening at USDA-Beltsville in 1993-94. Adv. Strawberry Res. 13:40-43.

Khanizadeh, S. and M.A. Fanous. 1992. Mathematical indices for comparing small fruit crops for harvest time and trait similarity. HortScience 27:346-348.

Kaps, M.L., M.B. Odneal, J.F. Moore, Jr., and R.E. Carter. 1990. Strawberry cultivar evaluation in Missouri. Fruit Var. J. 44(3):158-164.

Luby, J.J. 1989. Midwest and Plains States strawberry cultivars. Fruit Var. J. 43(1):22-31.

Maas, J.L., J.R. Harker, and G.J. Galletta. 1988. Occurrence of an exotic race of Phytophthora fragariae in Maine. Adv. Strawberry Res. 8:4244.

Nickerson, N.L. and R.A. Murray. 1993. Races of red stele root rot fungus, Phytophthora fragariae, in Nova Scotia. Adv. Strawberry Res. 12:12-16.

Ourecky, D.K. and M.C. Bourne. 1968. Measurement of strawberry texture with an Instron machine. Proc. Amer. Soc. Hort. Sci. 93:317-325.

Sacks, E.J. and D.V. Shaw. 1993. Color change in fresh strawberry fruit of seven genotypes stored at $0{ }^{\circ} \mathrm{C}$. HortScience 28:209-210.

Scott, D.H., J.L. Maas, and A.D. Draper. 1975. Screening strawberries for resistance to Phytophthora fragariae with single versus a composite of races of the fungus. Plant Dis. Rptr. 59:207-209.

Setzer, C.S. 1984. Color: reflections and transmissions. J. Food Qual. 6:183-197.

Wang, S.Y., G.J. Galletta, and J.L. Maas. 1996. Fruit quality characterization of 24 strawberry cultivars and selections. J. Small Fruit Viticult. (In press.)

Table 9. Earliness of flowering and plant characters (field rating scores) of 'Latestar' strawberry and several standard cultivars grown in matted-row beds in Beltsville, Md., in 1988 and 1994 and resistance to Phytophthora fragariae.

\begin{tabular}{|c|c|c|c|c|c|c|c|c|c|}
\hline \multirow[b]{3}{*}{ Cultivar } & \multirow{3}{*}{$\begin{array}{c}\text { Flower } \\
\text { stage }^{z} \\
1988\end{array}$} & \multicolumn{8}{|c|}{ Plant characteristic (rating) } \\
\hline & & \multicolumn{2}{|c|}{ Stand $^{\mathrm{y}}$} & \multicolumn{2}{|c|}{ Vigor $^{\mathrm{y}}$} & \multicolumn{3}{|c|}{ Leaf diseases ${ }^{y}$} & \multirow[b]{2}{*}{$\begin{array}{l}\text { P. fragariae } \\
\text { resistance }^{\mathrm{x}}\end{array}$} \\
\hline & & $\begin{array}{c}\text { Fall } \\
1987\end{array}$ & $\begin{array}{c}\text { Spring } \\
1988\end{array}$ & $\begin{array}{l}\text { Fall } \\
1987\end{array}$ & $\begin{array}{c}\text { Spring } \\
1988\end{array}$ & $\begin{array}{l}\text { Fall } \\
1987\end{array}$ & $\begin{array}{c}\text { Spring } \\
1988\end{array}$ & $\begin{array}{c}\text { Summer } \\
1988\end{array}$ & \\
\hline Allstar & $4.3 \mathrm{c}^{\mathrm{w}}$ & $7.9 \mathrm{a}$ & 8.2 & $8.5 \mathrm{ab}$ & $8.8 \mathrm{a}$ & $6.6 \mathrm{a}$ & $7.1 \mathrm{~b}$ & $5.6 \mathrm{bc}$ & $8.5(\mathrm{R})$ \\
\hline Lester & $5.5 \mathrm{~b}$ & $7.9 \mathrm{a}$ & 8.0 & $8.4 \mathrm{ab}$ & $8.0 \mathrm{ab}$ & $6.9 \mathrm{a}$ & $7.6 \mathrm{ab}$ & $7.6 \mathrm{a}$ & $8.5(\mathrm{R})$ \\
\hline Honeoye & $6.0 \mathrm{ab}$ & $7.4 \mathrm{ab}$ & 7.2 & $7.3 \mathrm{~b}$ & $7.5 \mathrm{~b}$ & $7.0 \mathrm{a}$ & $6.4 \mathrm{c}$ & $5.3 \mathrm{c}$ & $3.0(\mathrm{~S})$ \\
\hline Earliglow & $6.8 \mathrm{a}$ & $8.8 \mathrm{a}$ & 8.8 & $8.8 \mathrm{a}$ & $9.0 \mathrm{a}$ & $5.5 \mathrm{~b}$ & $7.0 \mathrm{bc}$ & $6.5 \mathrm{~b}$ & $8.5(\mathrm{R})$ \\
\hline Lateglow & $3.0 \mathrm{~d}$ & $7.9 \mathrm{a}$ & 8.5 & $7.2 \mathrm{~b}$ & $8.3 \mathrm{ab}$ & $6.0 \mathrm{~b}$ & $6.3 \mathrm{c}$ & $5.3 \mathrm{c}$ & 9.0 (VR) \\
\hline Latestar & $\begin{array}{c}2.6 \mathrm{~d} \\
1994\end{array}$ & $\begin{array}{c}6.4 \mathrm{~b} \\
1993\end{array}$ & $\begin{array}{l}7.4^{\mathrm{NS}} \\
1994\end{array}$ & $\begin{array}{c}8.0 \mathrm{ab} \\
1993\end{array}$ & $\begin{array}{l}8.0 \mathrm{ab} \\
1994\end{array}$ & $\begin{array}{l}6.6 \mathrm{a} \\
1993\end{array}$ & $\begin{array}{c}8.1 \mathrm{a} \\
1994\end{array}$ & $\begin{array}{l}5.1 \mathrm{c} \\
1994\end{array}$ & $7.8(\mathrm{R})$ \\
\hline Allstar & $5.0 \mathrm{~b}$ & $6.5 \mathrm{~b}$ & 6.3 & 7.8 & $8.0 \mathrm{a}$ & $7.5 \mathrm{a}$ & $5.8 \mathrm{c}$ & $--^{v}$ & \\
\hline Lester & $7.8 \mathrm{a}$ & $7.0 \mathrm{ab}$ & 6.8 & 7.8 & $7.5 \mathrm{a}$ & $7.0 \mathrm{a}$ & $6.5 \mathrm{ab}$ & --- & \\
\hline Earliglow & $8.8 \mathrm{a}$ & $7.5 \mathrm{ab}$ & 7.3 & 7.3 & $6.8 \mathrm{~b}$ & $6.3 b$ & $5.9 \mathrm{bc}$ & --- & \\
\hline Latestar & $2.0 \mathrm{c}$ & $7.8 \mathrm{a}$ & $7.5^{\mathrm{Ns}}$ & $7.5^{\mathrm{Ns}}$ & $8.0 \mathrm{a}$ & $7.5 \mathrm{a}$ & $7.1 \mathrm{a}$ & --- & \\
\hline
\end{tabular}

${ }^{\mathrm{z}}$ Ratings on a 1 to 9 scale with $1=$ few flowers open, $3=$ all primary flowers open, $5=50 \%$ open, $7=75 \%$ open, and $9=100 \%$ of the flowers open at the rating time.

${ }^{y}$ Ratings on a 1 to 9 scale with 9 being the most desirable.

${ }^{x}$ Ratings on a 1 to 9 scale of $1=$ plant dead to $9=$ plant apparently healthy. $\mathrm{R}=$ resistant; $\mathrm{S}=$ susceptible; VR $=$ very resistant.

"Means separation in columns within year by Duncan's multiple range test at $P \leq 0.05$. Ns indicates no significant differences among cultivars.

vot rated. 